\title{
Individual Counseling to Improve Knowledge And Affecting Healthy Sex Behavior for housewifes with High Risk of Hiv And Aids
}

\author{
Sri Mudayatiningsih ${ }^{1}$,Tri Johan Agus Yuswanto ${ }^{2}$ \\ ${ }^{1,2}$ (Health Polytechnic Of Malang, Republic Of Indonesia)
}

\begin{abstract}
Acquired Immune Deficiency Syndrome (AIDS) is a collection of symptoms caused by HIV. This virus attacks white blood cells that have CD4 cell receptor to damage human immune system resulting in decreased immune system that causes infections to happen easily. The virus is found in body fluids, especially on sperm, vaginal fluids and blood. Transmission occurs through unprotected sexual intercourse, blood transfusion, sharing nonsterilized needles, transplanted tissues/organ and transmission from pregnant women to her baby. (KPAN, Mboi .N., 2010). AIDS cases have been increasing from year to year as reported by KPAN which has reached to 30,430 cases in March 2012. The development of AIDS cases in women was 20\% in 2007, 25\% in 2008 to $27 \%$ in 2011. The proportion of AIDS cases among women increased by $2.3 \%$, demonstrating that the AIDS epidemic in Indonesia is increasing. HIV condition in Indonesia is in contrast with global conditions where the growth of new cases of HIV in several countries have declined while in Indonesia it has increased. The data up to March 2012 estimated that 6:58 million people were vulnerable to HIV infection, and the highest number was coming from male sex workers (3:17 million) and their wives with the amount of 1.94 million people. (Kompas.com., 2012). The purpose of this study was to find out healthy sex behavior of housewives at risk through health education on HIVdan counseling on AIDS in Malang.

This research used quasi experimental design with pretest-posttest onlydesign method. The analysis used t test with a score of 95\% conducted on 25 respondents of housewives who are at risk.The research found out that providing counseling on HIV/AIDS in housewives can change sexual behavior. Theresults of analysis got $p$ value of 0.000 which means that there is a significant difference means that individual counseling give a good effect on healthy sexual behavior change on risk groups. It is recommended for the improvement of this study that the sample selected to be respondents should get laboratory CD4 + examination first to determine and ensure that respondents are actually at risk groups, and samples were also taken from their spouses.
\end{abstract}

Keywords: healthy sexual behavior, housewives risk, individual counseling

\section{Introduction}

Epidemic diseases that became a serious problem faced by the world, including Indonesia, is the rapid growth of viral diseases, one of them is human immunodeficiency virus (HIV) that causes Acquired Immune Deficiency Syndrome (AIDS). AIDS is a collection of symptoms caused by HIV, the virus attacks white blood cells that have CD4 cell receptor and would damage the human immune system resulting in decreased immune system so that infections may happen easily. HIV only infects cells that carry membrane receptors that enable the virus to bind such "lock and key". The virus is found in body fluids, especially on sperm, vaginal fluids and blood. Transmission occurs through unprotected sexual intercourse, blood transfusion, sharing non sterilized needles, transplanted tissues /organ and transmission from pregnant women to her baby. (KPAN, Mboi .N., 2010).

AIDS case reports show an increase from year to year as reported from the by KPAN that until March 2012 it has reached to 30.430 cases. The development of AIDS cases in women are from 20\% in 2007, 25\% in 2008 to $27 \%$ in 2011 . The proportion of AIDS cases among women increased by $2.3 \%$, demonstrating the AIDS epidemic in Indonesia is also increasing. HIV condition in Indonesia is in contrast to global conditions, where the growth of new cases of HIV in several countries declined, while in Indonesia it has increased. Data up to March 2012 is estimated that 6:58 million people are vulnerable to HIV infection, and the highest number is coming from male sex workers (3:17 million) and their wives (1.94 million people). (Kompas.com., 2012)

The rate of transmission of HIV/AIDS in Malang, East Java, among mothers and children continues to increase since 1997, as stated by Nusindrati, the Head of Disease and Environmental Health Control, Public Health Service of Malang, to Kompas on Friday (30/11/2012). The number of people living with HIV in Malang today has reached to 2,021 people. About 15 percent of them or 3,006 people are housewives and couples at high risk, the second largest after Surabaya. Housewives were previously at low risk, the increase is due to the lack of knowledge of housewives about the transmission of the deadly disease and ignorance of how to handle the case of sexually transmitted infections (STIs). In addition, thehusbandsare less open to their wives about their unsafe sexual behavior.Minimum knowledge of housewives can be seen from their awareness to do check themselves to VCT (Voluntary Counseling and Testing) clinic. 
Data disease epidemic in Malang district is very worrying, because the number of people living with HIV/AIDS (PLWHA) has reached 287 people consisting of 181 people with HIV and 106 people with AIDS. HIV-positive Patients spread in four sub-districts of 40 districts, namely Gondanglegi (95), Sumberpucung (18), Dampit (15) and Lawang (14). The main cause of the spread of the virus is due to the high use of shared and non sterileneedles, and low use of condoms during sexual intercourse at risk, especially for transvestites and prostitutes (Health office, 2009). The latest data up to April 2013 shows that the number of HIV/AIDS cases in Malang was 872 people, and is likely to increase to 8,720 people, this refers to WHO prediction that stated that cases of HIV / AIDS is an iceberg phenomenon (KPAD Kab Malang). From the data, the top three of the six districts areGondanglegiwith 143 people, Dampit with 58 people, and Sumberpucung with 57 people. HIV / AIDS cases based on the age range of over 581 people are half of them, 310 people, are women and tends to increase by 30 percent annually. This condition is caused by the dishonesty of the couple, in addition to the female reproductive organs that allows the accommodation of much seminal fluid containing HIV/AIDS. Women are often late for check-up, in addition to the information and dissemination of HIV/AIDS areoften only prioritized in men.

HIV-AIDS epidemic area could adversely affect the welfare of people, so that it is necessary to conduct intensive program for reduction and prevention of HIV/AIDS as well as real support program to prevent HIV epidemic. Having this problem, all parties should contribute to prevent the spread of HIV in the community and raise awareness of housewives who are at risk of HIV to always be alert, aware and get health balanced information and sensitive to environmental conditions including the behavior of the husband in order to reduce the incidence of HIV-AIDS in the regency of Malang. Various counseling has been done but the need for selfunderstanding is needed too since these conditions allow differences in absorption of information that affects the person's behavior.

Based on the background of the above the problem can be formulated as "How is healthy sexual behavior of housewives at risk through health education with counseling methods about HIV and AIDS in Malang.

\section{General Objective}

The purpose of this study is to find out counseling effect on healthy sexual behavior in housewives who are at risk of HIV and AIDS

\section{Specific Objectives}

1. To identify the knowledge of housewives who are at risk of HIV/AIDS before and after counseling

2. To identify healthy sexual behavior in housewives who are at risk of HIV/AIDS before and after counseling

3. To analyze the effect of counseling toward healthy sexual behavior in housewives who are at risk of HIV and AIDS

\section{Framework}

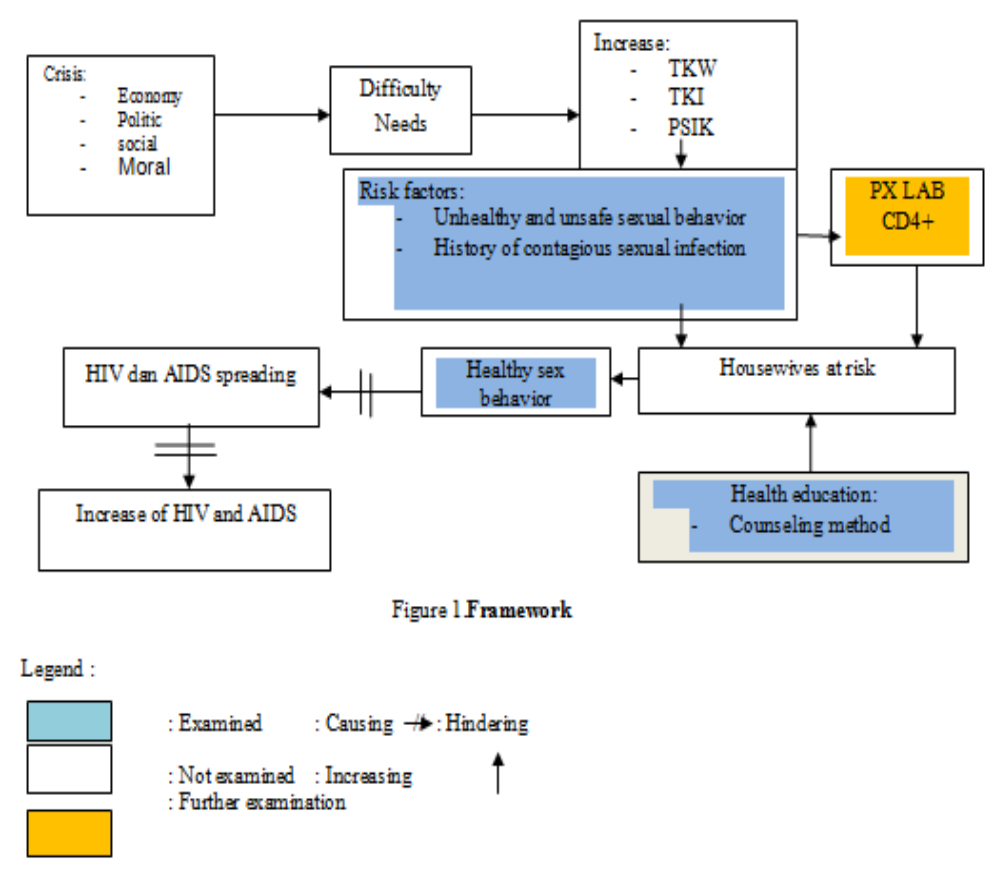




\section{Method and design}

This study is a Quasi-experimental design using pretest-posttest design conducted on housewives who are at risk, in order to determine the behavior of a healthy sex of housewives at risk through counseling about HIV and AIDS

\section{Population and Sample}

The study population was all housewives who are at risk of HIV/AIDS, with a population of 100 respondents. Purposivesampling technique was used to get the sample with the following criteria:

The inclusion criteria are as follows:

1. Married

2. Having a husband who was once a migrant worker,

3. Working abroad,

4. History of changing partners

5. Having a history of STIs (sexually transmitted infections)

6. Willing to be a respondent

\section{Research Variables}

1) Independent Variables:

Healtheducation with counseling methods of HIV/AIDS

2) Dependent Variables:

Healthysexual behavior in housewives who are at risk

\section{Research framework}

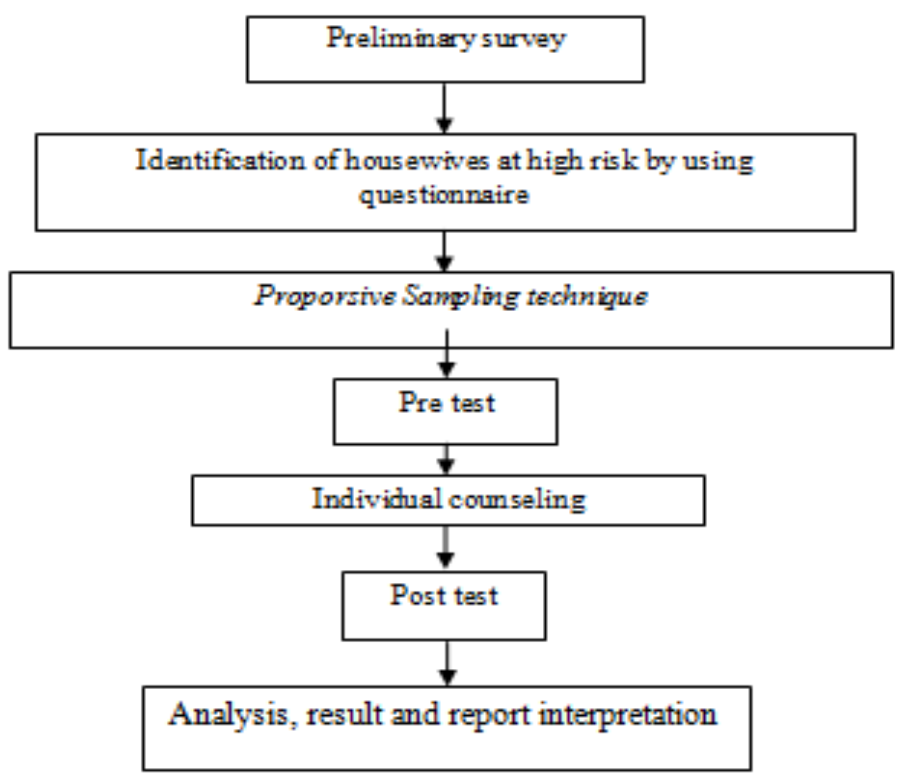

\section{Result}

\section{Result and discussion}

\section{Housewives knowledge about HIV/AIDS before counseling}

Table 3.1Respondent knowledge before counseling

\begin{tabular}{|c|c|c|c|}
\hline No & Knowledge & Frequency & Percentage (\%) \\
\hline 1 & Good & 11 & 44 \\
\hline 2 & Moderate & 7 & 28 \\
\hline 3 & Bad & 7 & 28 \\
\hline \multicolumn{2}{|c|}{ Total } & 25 & 100 \\
\hline
\end{tabular}

Table 3.1shows that respondents knowledge before counseling about HIV/AIDS are mostly (44\%) in good category and $(28 \%)$ in bad category 


\section{Housewives knowledge about HIV/AIDS after counseling}

Table 3.2.respondents knowledge after counseling

\begin{tabular}{|c|c|c|c|}
\hline No & Knowledge & Frequency & Percentage (\%) \\
\hline 1 & Good & 17 & 68 \\
\hline 2 & Moderate & 8 & 32 \\
\hline 3 & Bad & 0 & 0 \\
\hline \multicolumn{2}{|c|}{ Total } & 25 & 100 \\
\hline
\end{tabular}

Table 3.2 shows that respondents knowledge about HIV/AIDS after counseling is mostly (68\%) in good category and a small part of them $(32 \%)$ is in moderate category

Table 3.3t testcalculation result about housewives with HIV/AIDS risk before and after counseling

\begin{tabular}{|c|c|c|c|c|c|}
\hline \multicolumn{2}{|c|}{ Variable } & $\mathrm{N}$ & $\begin{array}{c}\text { Significance } \\
\text { level } \\
\text { (2-tailed) }\end{array}$ & $\begin{array}{c}\text { Lower } \\
\text { limit }\end{array}$ & Upper limit \\
\hline \multirow{2}{*}{ Knowledge } & Before & 25 & .000 & 9.77 & 12.63 \\
\cline { 2 - 6 } & After & 25 & .000 & 17.99 & 18.97 \\
\hline
\end{tabular}

From $t$ test we got significance level of $0.000<\alpha=0.05$, so that it can be concluded that there is a significant difference between before and after counseling about HIV/ AIDS on those housewives.

\section{Housewives behavior about HIV/AIDS before counseling}

Table 3.4respondents behavior before counseling

\begin{tabular}{|c|l|c|c|}
\hline No & \multicolumn{1}{|c|}{ Knowledge } & Frequency & Percentage (\%) \\
\hline 1 & Good & 7 & 28 \\
\hline 2 & Moderate & 16 & 64 \\
\hline 3 & Bad & 2 & 8 \\
\hline \multicolumn{2}{|c|}{ Total } & 25 & 100 \\
\hline
\end{tabular}

Table 3.4 shows that healthy sex behavior of respondents before counseling about HIV/AIDS is mostly (64\%) in moderate and a small part $(8 \%)$ is in bad category

\section{Housewives behavior about HIV/AIDS after counseling}

Table 3.5 Respondents behavior before counseling

\begin{tabular}{|c|l|c|c|}
\hline No & Knowledge & Frequency & Percentage (\%) \\
\hline 1 & Good & 6 & 24 \\
\hline 2 & Moderate & 16 & 64 \\
\hline 3 & Bad & 3 & 12 \\
\hline \multicolumn{2}{r|}{ Total } & 25 & 100 \\
\hline
\end{tabular}

Table 3.5 shows that respondents behavior before counseling about HIV/AIDS is mostly (64\%) in moderate category and a small part (12\%) is in bad category

\section{Counseling effect toward healthy sex behavior on housewives with HIV and AIDS risk}

Table3.6Result of t testabout healthy sex behavior of housewives with HIV/AIDS risk before and after counseling

\begin{tabular}{|c|c|c|c|r|r|}
\hline \multicolumn{2}{|c|}{ Variable } & N & $\begin{array}{c}\text { Significance level } \\
\text { (2-tailed) }\end{array}$ & Lower limit & $\begin{array}{c}\text { Upper } \\
\text { limit }\end{array}$ \\
\hline \multirow{3}{*}{ Behavior } & Before & 25 & .000 & 8.09 & 10.39 \\
\cline { 2 - 6 } & After & 25 & .000 & 7.44 & 9.68 \\
\hline
\end{tabular}

$t$ testresult shows significance level of 0.000 . The significance value is $<\alpha=0.05$, so that it can be concluded that there is a significant difference in behavior before and after counseling about HIV/ AIDS on housewives at risk. 


\section{Discussion}

\section{Knowledge of housewives who are at risk of HIV/AIDS before and after counseling}

This study showed that there is an increase in housewives knowledge who are at risk of HIV/AIDS before and after health education with counseling method in good category (44\%) which increases to (68\%) and only a small proportion (28\%) who have less knowledge at the beginning is increasing to (32\%). This condition can indirectly affect a person's behavior in their decision making for everyday life. Individual counseling method is a more clinical approach that stresses sex as natural healthy function. Physical problem (pain, infection, or drugs) can affect sexual pattern response. Psychological problems (anxiety, sin, shame, depression, or conflict) can also disrupt sexuality pattern. Some approach on sex sometimes cause conflicts, but relatively depending on the time, place, and circumstances, moral and cultural background. Some opinions and views that state women are completely passive and receiving, while men are more active and aggressive is a wrong concept because that will cause women or mothers tend to be at risky behavior compared to the actual behavior. So, a good knowledge about healthy sexual behaviors can prevent the risk of transmission of some diseases as a result of the wrong sex. Health education with individual counseling method as well as clear and open communication will provide good insight on someone.

Sexual education efforts are to educate by increasing knowledge and directing to correct sexual behavior. That is, a healthy sexual behavior that emphasizes the physical or psychological aspect that will lead to better healthy sex for themselves and others (Widjanarko, 1994). Some frequent sexual health problems are associated with sexually transmitted disease such as gonorhoea, chlamydialinfections syphilis, chancroid, genital herpes, viral hepatitis, genital warts, molluscumcontagiosum, public lice, and vaginal infections (Masters, Johnson and Kolodny, 1992). By knowing variety of STDs, everyone can manage their sexual libido in accordance with their values and culture. One of the ways to have healthy sexual behavior is by doing some precautions by controlling sexual behavior, looking for information about STDs, carefully selecting sexual partners, conducting laboratory tests if there is a change in genitalia, early and appropriate treatment, and be alert to changes that occur on the body especially to the genitalia (Allegeier\&Allegeier, 1991).

The problem is how the knowledge about sexual behavior can be delivered to housewives who are at risk for HIV/AIDS. This information has a major role and effect in someone's life. Aristoteles stated (in Fisher, 1986) that information can be used to change behavior. King (in Fisher, 1986) states that information can direct someone to achieve their goals also to overcome their problems. By discussing sex behavior with a counselor will be able to prevent unhealthy sexual behavior. Good information about healthy sex will improve the level of knowledge of sex and will have a direct impact on sexual behavior.

Sexual education can be done using various techniques such as by giving lectures, brochures, and discussions. Whena person receives a persuasive message then they will digest the information and make arguments. These conditions may be linked to the amount of cognitive effort required. If the message is considered as important information and according to personal needs, there will be a central route. Cognitive activity that occurs is to evaluate the strength and rationality of argument so that information can be approved. When information is considered to be unimportant, persuasion will occur in the peripheral route. In this case cognitive work is limited and if the change of attitude cause more persuasive information relating to the source based on the source prestige, credibility, or others; or the style of messages resented -and not the quality of the argument.

Lecturing technique used in health education needs more active role from communicator and the audeience need for argumentation is relatively little. Capability for argumentation is really needed so that the researchers also used some brochures related to knowledge about sex that are at risk of HIV/AIDSthat are created with simple language so that the needs to digest the information argumentatively will be less. These conditions are likely to improve the knowledge of housewives who are at risk by $61.1 \%$ in moderate category. Based on its characteristics, the housewives are in need of some information that can be absorbed and understood well or included in high need for cognition category.

Changes in knowledge about healthy sexual behavior will be better in comparison with brochures and lectures which relatively need less in digesting the information. So the method of individual counseling will give stronger effect in increasing knowledge of healthy sex.

\section{Healthy sexual behavior in housewives who are at risk of HIV/AIDS before and after counseling}

The result showed a fundamental change from before and after counseling, while the behavior of majority (64\%) is in moderate category, but there is some which are decreasing. This proves that the behavior change is not absolutely influenced by knowledge alone but requires an awareness of the individuals themselves as well as many other influencing factors.

Housewives are a group has a lot of health risks. This condition is due to their specific characteristic in cognitive level and reasoning to understand and decide something logically, but on the other hand they get pressure from their partners which cause them to have irrational behavior. In such situation, a housewife is more 
influence by her sexual partner, thus indicatingrisk-taking behavior.Other influential factors are many advertisement about unhealthy products such as cigarette, beverages and food that are considered to be luxurious. Health service for housewives at risk requires a more educative approach. Communicative interaction between health care provider and them are really needed, in addition to the necessary health care.

Provider-clientinterface to give a deep interpersonalcommunication is needed to give stressing on interpersonal aspect in service implementation. Simmons states that fostering interpersonal relationship is not something easy because it is influenced by good attitude of the presenters (providers) and patients or client. Health problems are no longer viewed as a paradigm of biomedical but more on biopsychosocial approach, therefore health service is not just "medical service" but as "public health service" which refers to assumption that health is influenced by epidemiological, economic, and social demography needs. There are attitudes, behaviors, socio-cultural background and a number of other aspects social aspect (Anwar, 1996). Also effective, efficient, innovative, and quality health services in accordance with society needs. Besides, medical technology is getting more advanced and health care model through health education counseling method is very useful for groups that are at risk in healthy behavior quality (Sarafino, 1990). Stress and environmental factors need causes someone to have risky life style. To develop healthy lifestyle of teenagers, communicative and interactive care model need to be elaborated.

HIV transmission happens sexually when there is a contact between the vaginal secretions of someone with a preseminalorrectum secretion, genital, or mucous membranes in partner's mouth. Receptive unprotected sexual intercourse has bigger risk than insertive intercourse with no protection, and the risk of unprotected anal intercourse is bigger thanregular and oral sex. Oral sex does not mean no risk for HIV can get through receptive oral sex and insertive sexual. Sexual violence also increases HIV transmission because generally they do not use protection and frequent physical trauma on vagina can facilitate HIV transmission. HIV transmission depends on the level of the index and the vulnerability of the partner. Level of transmission is different at different stages of the disease and inconstant between individuals. Every 10 times of the increase in the number of blood plasma HIV RNA is equal toa $81 \%$ increase in the rate of transmission. Woman is more vulnerable due hormone change, ecology and physiology of vaginal microbae, and greater vulnerability against sexual disease. People with HIV can still be infected by other deadly disease.

Sexually transmitted infections require continuous observation and early detection it is one of the doors for the spread of HIV. It is specifically has the aim to have description about the epidemiology of sexually transmitted infection, and factors effecting the progression of the disease, so that it can continuously and systematically provide epidemiological support and information about the prevention. Monitoring the level of emergency analysis through morbidity is needed following the trend of the incidence, risk factors for disease detection and early prevention for extraordinary events in order to ensure resources on vulnerable groups.

\section{The effect of healthy sexual behavior of housewives who are at risk of HIV/AIDS before and after counseling}

The analysis showed no significant differences in healthy sexual behavior on housewives who are at risk of HIV/AIDS before and after health education with counseling methods. This can be explained that housewives are groups at high risk of transmission of diseases caused by unhealthy sexual behaviors that can impact physically, psychologically and socially. More cases on sexually transmitted diseases, especially HIVAIDS is caused by their unhealthy sexual behavior. Thenumber increases and causes maternal morbidity and mortality. This problem cannot only seen clinical aspect. The core of the problem lies on the complex social context for reproductive health, political, social and economic and closely linked to values, ethics, religion and culture. For that matter, efforts from many parties are needed.

Effects of Social Change on unhealthy sexual behavior with high risk, both during pregnancy and when giving birth.The high risk is not only the pain, but also the risk of death and disease prevention.

Statistical analysis showed no significant difference in the healthy sexual behavior on housewives who are at risk through health education with counseling method about HIV/AIDS before and after counseling. This means that health education with individual counseling method gives a good effect on healthy behavior change. Housewives with little education and no information about the diseases caused by unhealthy sexual behavior of their partners have a tendency to have unsafe sex compared to those with good education.

This condition is caused by environment factorwhich is one of the driving factors of unhealthy sexual behavior. These environmental factors come from the media and television, economic factors and demands of life itself.

Effect of unclear and difficult information often leads to changes in everyday behavior. Some of the difficulties that arise later is less open attitude and no understanding on sexual behavior. This means that sex information is not correct or not suitable with one's needs resulting in wrong behavior and outlook towards sex so that causesconflicts and false ideas and fears associated with sex.

Statistical analysis showed that there were statistically significant differences with $p=0.000$ at 0.05 alpha in healthy sexual behavior in housewives who are at risk of HIV/AIDS before and after health education

DOI: 10.9790/1959-0602020108 $\quad$ www.iosrjournals.org 6 Page


counseling methods. This means that healthy sexual behavior is closely related to the sexual behavior. Predisposed attitudes are not always be manifested. Attitudes and behaviors can be consistent if attitudes and behavior in question is specific and relevant. Since permissiveness and healthy sexual behavior is specific and relevant to one another, then that attitude could be predictor for the attitudes. There is a significant difference with $\mathrm{p}=0.000$ at 0.05 alpha which means there is a significant difference between sexual behavior before and after given health education with counseling methods to housewives at risk with healthy sexual behavior.

Many external factors influence healthy sex behavior. Several other factors are knowledge, the environment, and the life of family, friends, and communities and other factors can be identified from healthy sex behavior. Healthy sex behavior is not something that can be seen directly but it doesn't also happen directly. It must be motivated by internal factors that cannot be observed directly ..

Housewives' healthy sexual behavior may be motivated by compassionand love be dominated by feelings of closeness and passion of their partners, with no pressure and fear. This is due to the influencer norms that have the most influence. Internal factor for sexual behavior that leads to unhealthy sex behavior is a growing sexual organ. Sexual glands growth not only affecting body growth but also physical life, moral, and social life.In one's psychic life, sexual organ development has strong influence in healthy sexual behavior against the opposite gender. If sexual desire is too strong it can create conflicts, then that sex drive will be won due to some justifications. The effect of sexual organs development in a person's social life can affect healthy sexual behavior of one's partner.

\section{Conclusion}

\section{Conclusion and Recommendation}

1. Provision of individual counseling on HIV/AIDS can increase housewives' knowledge

2. Provision of individual counseling on HIV/AIDS can change sexual behavior of housewife at risk

3. There are significant differences of healthy sexual behavior in housewives who are at risk of HIV/AIDS before and after counseling,

4. Individual Counseling can affect healthy sexual behavior in housewives who are at risk

\section{Recommendation}

1. Selection of samples selected to be the respondents should haveCD4 +laboratory tests previously to ensure that respondents are actually at risk groups

2. Collection of data to support respondents data should not only data from housewives who are at risk, but also from their partners

3. Further research is needed to determine the effect of health education with counseling method in reducing the incidence of HIV/AIDS in high-risk housewives

\section{References}

[1]. Anonimous, 2008, Epidemi HIV/AIDS dan Upaya Penanggulangannya di Kabupaten Malang, Laporan Dinas Kesehatan

[2]. Aditya, BJ. 2005. Kerentanan Perempuan Terhadap HIV/AIDS dalam Jurnal Perempuan No.43: Melindungi Perempuan dari HIV/AIDS.

[3]. Akeke V., Mokgatle M., \& Oguntibeju O. (2007). Knowledge, Attitudes and Practices that Facilitate the Transmission of HIV among Prison Inmates: Areview. The Kuwait Medical Journal, 39 (4): 310-318. http://www.kma.org.kw/KMJ/Issues/dec2007/Review\%20Article/031-007\%20Knowledge\%20Attitudes.pdf [Diakses, 25 Juli 2008]

[4]. AI-Serouri, A.W., Takioldin, Ashish, H., Aldobaibi. A. \& Abdelmajed, A. (2002), Knowledge, attitudes and beliefs about HIV/AIDS in Sana'a Yemen. Eastern Mediterranean Health Journal Volume 8, No. 6, November 2002. http://www.emro.who.int/publications/ emhj/0806/ knowledge.htm: [Diakses 30 Desember 2008].

[5]. Boskey, Elizabeth., What Is the difference between HIV and AIDS ? About.Com Guide Updated April 02, 2012 Abaout.Com Health's Diseases and Condition content is reviewed by our Medical Review Board.

[6]. Bibi, P., Panda, P., Purty, AJ. \& Bazroy, J. (2006), Awareness on HIV/AIDS among Women in Refugee Community. Indian Journal of Community Medicine, Vol.31, No. 3 (2006-07 - 2006-09): http: //medind.nic.in/iaj/t06/i3/iajt06i3p208.pdf [Diakses, 30-10- 2007].

[7]. Butar-butar, T. G., Supardi, S. \& Paramastri, I. (2003), Kemampuan Negosiasi Pekerja Seks Jalanan dalam Pengunaan Kondom terhadap Pencegahan Penyakit Menular Seksual dan HIV/AIDS di kota Jayapura. Berita Kedokteran Masyarakat, BKM/XIX (3), pp. 107-116

[8]. Corey.G.2009. Teori dan Praktek Konseling dan Psikoterapi. Bandung, Refika Aditama

[9]. Departemen kesehatan, derektorat jendral Pengendalian Penyakit dan Penyehatan Lingkungan. Laporan perkembangan situasi HIV dan AIDs di Indonesia, Triwulan IV, 2008, Jakarta: Departemen Kesehatan , 2008

[10]. -----------, Penularan HIV pada Ibu Rumah Tangga Lebih Tinggi dari Pekerja Seks Kesehatan, News http://www.igama.or.id/2012/12/ 
[11]. Komisi Penanggulangan AIDS Nasional, 2012, Epidemi HIV di Indonesia dan Peran Perguruan Tinggi, Makalah disampaikan dalam Pelatihan Staf Pengajar FK. FKM, Pendidikan Keperawatan dan Kebidanan untuk Penerapan MA. HIV/AIDS, Surabaya tanggal 13-18/6/2012

[12]. Prayitno.2009. Dasar-dasar Bimbingan Konseling. Jakarta.Rineka Cipta

[13]. Murni,S.C.W. Green, S. Djauzi, A. Setiyanto, dan S. Okta, 2003. Hidup dengan HIV/AIDS. ISBN 979-97494, Yayasan Spiritia, Yogyakarta

[14]. Saradisastra,K.1998. Perspektif Keterlibatan wanita di Sektor Pertanian, Forum Penelitian Agro Ekonomi

[15]. Sunardi,Permanarian,Assjari.M.2008. Teori Konseling.PLB FIB UPI 